\title{
THE CONCEPT OF THE DYNAMIC SEMANTIC SCALES IN THE THEORY OF FSP REVISITED
}

[La notion des échelles sémantiques dynamiques dans la théorie de la perspective fonctionnelle de la phrase]

\author{
Martin ADAM \\ Irena HEADLANDOVÁ KALISCHOVÁ \\ Masaryk University, Brno
}

\begin{abstract}
En): The theory of functional sentence perspective (FSP) and its research methods have been considered one of the prominent tools of research into information processing. It is widely known that, combining the approaches adopted both by formalists and functionalists, the theory of FSP draws on the findings presented by the scholars of the Prague School, particularly by Vilém Mathesius. Mathesius observed the language universal of every utterance having a theme and a rheme, and formulated the basic principles of what was to be labelled FSP only later. In the framework of FSP every sentence implements one of the so-called dynamic semantic scales (FIRBAS, 1992), which functionally reflect the distribution of communicative dynamism and operate irrespective of word order. Principally, Firbas distinguishes two types of the dynamic semantic scales: the Presentation Scale, in which a context-independent subject is presented on the scene, and the Quality Scale, where a specifying quality is ascribed to the subject. The present paper sets out to discuss the concept of the dynamic semantic scales from a diachronic point of view.
\end{abstract}

Résumé (Fr): Un résumé détaillé en français se trouve à la fin du texte.

Keywords (En): FSP; dynamic; semantic; scale; presentation; quality; Firbas; Mathesius

\section{Forefathers of FSP}

It would be impossible to cover all the names of linguists and philologists who have touched on the subject of information structure in one way or another over the centuries; indeed, one could go back as far as Aristotle and his terms hypokoimenon and katēgoróumenon introduced in connection with his theory of truth and applied also to grammatical analysis. Yet, the truly pioneering work of at least some of the key representatives in the field has to be acknowledged. Following is a list, albeit limited, of five scholars whose contribution to the development of the theory is of undisputed importance.

Henri Weil, a German-born French classical philologist, who published a comparative study titled De l'ordre des mots dans les langues anciennes comparées aux langues modernes in 1844 (in 1877, the book was translated into English and published as The order of words in the ancient languages compared with that of the modern languages). In this work, Weil reached the conclusion that a sentence contains a point of departure (an initial notion) and a goal of discourse, and that the movement from the former to the latter corresponds to the movement of the mind (FIRBAS, 1979: 30).

Sámuel Brassai, a contemporary to Weil, was a Hungarian linguist, methodologist, mathematician and philosopher, to mention at least the most important of his activities, and he too studied the word order principles operating in his mother tongue as well as other Indo-European languages. He published the 
results of his research in the treatise A magyar mondat I (The Hungarian sentence) in 1860, claiming that "the word order rules in Hungarian cannot be formulated in terms of grammatical subject - grammatical predicate, word order is determined by topic-comment articulation; [...] typically, the topic occupies the sentenceinitial position and it is followed by the comment" (KIEFER, 2005: 259). Brassai argued that basically in all the languages that he studied he could trace a common structure, starting with one or more elements carrying information already known which then points to the message or principal part of the sentence (BRASSAI, 1860: 341 in KIEFER, 2005).

Weil's ideas were revisited at the end of the $19^{\text {th }}$ century in the work of two German linguists, Georg von Gabelentz and Hermann Paul. Gabelentz, apart from sinology - the main field of interest to him, went along similar lines like Weil concerning word order and information structure. He was probably the first to introduce the distinction of psychological subject and psychological predicate and their separation from the grammatical subject / predicate. Paul, one of the representatives of the Neogrammarian (Junggrammatiker) school of linguistics and a distinguished expert on the history of language, dealt also with topics more than relevant to the theory of FSP, such as the potentiality of sentence meaning and the way in which context determines the structure of a sentence (SGALL et al., 1980: 142).

The following name refers to a linguist and philosopher who represents a direct link between one distinct current in linguistics and philosophy of language in Europe at the beginning of the $20^{\text {th }}$ century and the future Prague Linguistic Circle. Anton Marty, of Swiss origin, spent most of his academic career at the German part of the Ferdinand Charles University in Prague and his lectures on the philosophy of language were attended, among others, by Vilém Mathesius. Here, Marty revealed his "inherently content oriented theory of description of language, whose functional and instrumental orientation made it possible to rely on simple evidence in establishing differences and identities in meaning" (LEŠKA, 2002: 91). His earlier study on the separation of the grammatical, logical and psychological subject and predicate, published in 1897, is certain to have influenced and encouraged Mathesius in his research as these were thoughts that resonated with his own.

\section{Vilém Mathesius (the Prague Linguistic Circle)}

Just as Anton Marty's ideas provided a desired stimulus for Vilém Mathesius, Mathesius himself represented an inextinguishable source of inspiration to other members of the Prague Linguistic Circle (PLC). This body of linguists and literary critics, which declared its official existence in October 1926, based many of the theses of functional structuralism on Mathesius's ideas formulated even earlier, particularly in his paper On the potentiality of linguistic phenomena. Also, in Mathesius's approach, the whole issue of word order, sequence of ideas and psychological subject / predicate was brought to a new, higher level. He viewed the sentence as a basic functional tool in the communication process and characterized its most important feature as "the reaction of the speaker to some reality" (MATHESIUS, 1975: 81) thus laying emphasis on the dynamic nature of 
sentences / utterances (as opposed to the traditional formal analysis considering a sentence a static body).

In his writings we find a clear distinction between two constituting elements of a sentence, namely the "theme" (that is what is being talked about) and the "rheme" (that is what is being said about the theme) ${ }^{1}$; this division, as he pointed out, ranks as a language universal of every meaningful utterance. Drawing on his thorough investigation into the word order principles in Czech, he argued for the existence of an "unmarked (objective)" order of the two constituents, i.e. theme $\Rightarrow$ rheme

(1) He bought a house.

and the reversed sequence of the constituents, termed as "marked (subjective)", possibly signalling an emotive flavour, i.e. rheme $\Rightarrow$ theme

\section{(2) A new guest arrived.}

In Mathesius's interpretation, word order represents the sole means of FSP, therefore English with its word order system governed primarily by the grammatical principle was viewed as "little susceptible to the requirements of FSP" (FIRBAS, 1992: 120) unlike Czech, which complies readily with the unmarked sequence of theme followed by rheme. This is perhaps the only area that had to be subjected to further research showing that there are other factors which function as effective means of FSP (see section 3 below). Apart from that, however, it may be feasible to say that one hundred years ago Mathesius formulated and outlined the basic platform of the theory of FSP, which has served as a point of departure to several generations of linguists since.

\section{Jan Firbas (the Brno branch of PLC)}

If there were just one name to choose among the successors of Mathesius and his legacy in the field of FSP, then it is without a doubt that of Jan Firbas, the key figure of the Brno approach, who expanded Mathesius's ideas and advanced the whole theory of FSP to an unprecedented level of elaboration. Within Firbas's conception, a sentence is understood as a distributional field of communicative dynamism (CD); this is the extent to which linguistic elements conveying some meaning contribute to the further development of the communication (FIRBAS, 1992: 16-17). On the level of written language, three factors (or rather their interplay) determine the distribution of $\mathrm{CD}$; they are joined by the fourth factor in spoken communication:

- linear modification (i.e. word order)

Having studied in great detail the systems of word order in Czech and English, Firbas concludes that their respective operating principles differ considerably. While in Czech the leading principle is the "FSP linearity principle" (FIRBAS,

\footnotetext{
${ }^{1}$ It has to be noted that Mathesius was not the only one to use the terms "theme" and "rheme", e.g. H. Ammann mentioned them in 1911, but it was not until Mathesius's systematic treatment of the aspects and factors of FSP that these terms were assigned their distinctive roles.
} 
1992: 118), allowing the sentence elements to be ordered in accordance with a gradual rise in $\mathrm{CD}$, an English sentence has to satisfy the requirements of the ordering according to the syntactic functions of individual elements (ibid.).

- context

The highest rank in the FSP-factors hierarchy is occupied by the contextual factor; indeed, the notion of context is fundamental to most studies on information structure and discourse analysis (HEADLANDOVÁ, 2010: 33). Firbas's view is concerned with the concept of immediately relevant context which represents only a "fraction of the complex phenomenon of context" (FIRBAS, 1992: 21-40). A piece of information is regarded old (context-dependent) or new (contextindependent) in respect to its retrievability or irretrievability from the immediately relevant context; this is a crucial process in the distribution of CD over individual sentence elements.

- semantics

This factor stands for the semantic character of a linguistic element as well as its semantic relations to others, and the impact these have on the distribution of CD. Firbas maintains that within a distributional field, it is either the verb or dynamically stronger elements that complete the development of the communication, and in line with this claim he identifies two dynamic semantic scales and their constituents (see below).

- intonation

The last FSP factor operates only on the level of spoken language where the distribution of CD is determined by the interplay of all four factors; a sentence is perspectived towards the element with the highest degree of $\mathrm{CD}$ and it is this element that almost invariably becomes the intonation centre bearer (cf. also HeAdlandová, 2010). The works of both Czech and English phoneticians suggest that intonation not only reflects the CD of elements as determined by nonprosodic factors but can also disambiguate their interplay, or possibly increase the degree of CD assigned to an element.

As mentioned above, Firbas devised two dynamic semantic scales, which have proved a powerful tool for linguistic analyses of information processing. Their distinction is based on the way a sentence is oriented:

- a sentence may introduce a phenomenon to the discourse and so is perspectived towards the subject $\leftarrow$

- a sentence says something new / context-independent about the subject and is thus perspectived away from the subject $\rightarrow$

The first case is represented by the Presentation Scale, the other by the Quality Scale. In the examples below, the rhematic part is in bold while the underlined elements stand for the transition between the rhematic and thematic parts. It has to be noted that the scales, as outlined here, offer the interpretative, not the actual linear arrangement of a sentence; these two may or may not overlap. Also, the implementations of the scales do not necessarily contain all the constituents. 


\section{Presentation Scale (Pr-Scale)}

- a phenomenon is presented on the scene

- such an utterance features "existence or appearance on the scene with explicitness or sufficient implicitness" (FIRBAS, 1995: 65)

Setting (Set) - Presentation of Phenomenon (Pr) - Phenomenon Presented $(\mathrm{Ph})$

(3) V̌̌ude bylo světlo. ${ }^{2}$

Set $\quad \mathrm{Pr} \quad \mathrm{Ph}$

[Everywhere was light.]

(4) Suddenly, a newcomer appeared on the platform.

Set $\quad \mathrm{Ph} \quad \mathrm{Pr} \quad$ Set

\section{Quality Scale (Q-Scale)}

- a quality (its specification) is ascribed to a (typically) context-dependent subject

- the verb can fulfil two different functions, either the notional component expresses the quality or, in case of copulas, it carries out merely the act of ascription while the quality is expressed by a non-verbal element (FIRBAS, 1992: 66 - 86).

Setting (Set) - Bearer of Quality (B) - Ascription of Quality (AofQ) - Quality (Q) - Specification (Sp) - Further Specification (FSp)

(5) Carefully, he put the letter in the envelope.

Set B Q Sp FSp

(6) Ten muž nesl těžký kufr.

B $\quad \mathrm{Q} \quad \mathrm{Sp}$

[The man carried a - heavy suitcase.]

\section{Recent Research: Svoboda, Chamonikolasová, Adam}

In a natural, authentic language, the two basic scale configurations may be found in two more variants: the so-called Combined Scale and the Extended Presentation Scale.

In the typology of sentence perspective scales, the Combined Scale stands in between the Presentation and the Quality Scales. FIRBAS (1992: 67) as well as SVOBODA (1989: 14-15) interpret it as a merger of the two basic perspectives. The Combined Scale implementation means that a Phenomenon is being presented and, at the same time, something new is said about it by means of Specification (cf. Chamonikolasová, AdAM, 2005: 217-229). In such cases, FirBAS (1992:

\footnotetext{
${ }^{2}$ All examples in the Czech language in this paper will be supplemented with an English word-forword translation in square brackets ; the hyphenated analytical forms correspond to their Czech equivalents expressed by single words.
} 
67-68) says that the distributional field "telescopes the Ph-function and the Bfunction into the subject", reflecting the following usual version of interpretative arrangement (the example is taken from FIRBAS, 1992: 67):

Setting (Set) - Phenomenon Presented (Ph) - Bearer of Quality (B) - Quality (Q) - Specification (Sp)

(7)

$\begin{array}{lll}\text { Ages ago } & \text { a young king } & \text { ruled } \\ \text { Set } & \text { Ph-B } & \mathrm{Q}\end{array}$

capriciously and despotically. $\mathrm{Sp}$

However, CHAMONIKOLASOVÁ (2005) and, consequently in CHAMONIKOLASOVÁ and ADAM (2005), showed that the semantic structure of the sentence above and the like corresponds almost precisely to the Quality Scale, differing only in the absence of a previous introduction of the subject (Pr) into the context of communication. In other words, what Firbas labels a Combined Scale may actually be abandoned and readily re-evaluated as a variant of the pure Quality Scale.

There is, nevertheless, another sentence type that may be regarded as somewhat special within the traditional Firbasian framework of dynamic semantic scales, viz. the Extended Presentation Scale. Its existence and structure were first described in ADAM (2003: 129-134) within his FSP analysis of biblical discourse (in this study, such sentences are, in accord with later Chamonikolasová's conception, denoted as presentation sentences containing a "double rheme" ). The occurrence of such a double rheme in certain types of presentation sentences was identified in several passages of the Gospel according to Matthew and Luke (The New Testament, New International Version of the Holy Bible; see ADAM, 2003). Some distributional fields displayed a considerable degree of potentiality, which creates difficulties in the interpretation of dynamic semantic functions. The structure of sentences implementing this type of interpretative scale actually corresponds very closely to the Presentation Scale, differing only in the presence of the Specification, which is not part of the "pure" Presentation Scale as defined by Firbas.

Setting (Set) - Presentation of Phenomenon (Pr) - Phenomenon Presented (Ph) Specification (Sp)

\section{(8) In these days John the Baptist came preaching in the Desert of Judaea. Set $\quad \mathrm{Ph} \quad \mathrm{Pp}$}

To sum up, recent research into the area of the dynamic-semantic scales has confirmed the applicability of the modification of the original framework of dynamic semantic scales developed by FIRBAS (1992) and supplemented by SVOBODA (1989). The modification consists in the recognition of the occurrence of a Specification within the Presentation Scale in semantically dense sentences (CHAMONiKOlasová, AdAM, 2005). As a result, a modified framework, which abandons Firbas's concept of the Combined Scale associated with certain Presentation Scale patterns (i.e. patterns implementing the Extended Presentation 
Scale) and certain Quality Scale patterns (i.e. patterns in which the B-element had not been introduced in the previous context) was introduced. The modification is obviously compatible with the original framework and contributes to a more precise analysis of language in the act of communication.

Apart from the Presentation, Quality and Combined Scales, SvoBodA (2005) also distinguishes the so-called Bifunctional or Multifunctional Pr / Q Scale. By this variant he means sentences in which it is almost inevitable to accept a potentially double interpretation, such as in the following example (in Svoboda's opinion, such cases are said to occur typically in poetic, literary discourse):

\section{(9) Raindrops tapped on the tin roof.

$\mathrm{Ph} / \mathrm{BPr} / \mathrm{QSet} / \mathrm{Sp}$

\section{The English Transitional Verb}

Within the interplay of the basic FSP factors (context, linear modification, and semantics), the scholarly attention paid to the syntactic nature of the transitional verb has been slightly one-sided even though the verb represents a crucial element in FSP interpretation. Whereas the verb is well-researched in the area of its FSP (i.e. dynamic semantic) qualities (among other qualities its tendency to act typically in the transition layer or the double-sided capacity to interconnect the theme and the rheme), the static semantic character of the English verb especially against the background of its syntactic structure - has been addressed only occasionally and usually primarily in relation to other linguistic issues (cf. FIRBAS, 1992, 1995, DUŠKOVÁ, 1998, 2008, ADAM, 2009, 2011a, 2011b, 2011c, CHAMONIKOLASOVÁ, ADAM, 2005).

In other words, it seems that a minute static semantic analysis of the Presentation verbs (hereafter abbreviated Pr-verbs) may throw some light on the character of the English transitional verb operating in both the dynamic semantic scales. To illustrate this, there is, as a rule, a direct, straightforward relationship between FSP tripartite functions (theme - transition - rheme) on the one hand and corresponding dynamic semantic roles (functions) on the other: for instance, the Bearer of Quality or the Setting is always thematic, or the Specification is inevitably rhematic (cf. DUŠKOVÁ, 2008: 71). Nevertheless, the situation is remarkably different in the case of the verb that - in both the Presentation and the Quality Scales - forms the transition of the sentence, or, if there is no successful competitor in the distributional field, the rheme. Thus, only the verb represents a potentially heterogeneous, double-faced element capable of fulfilling two dynamic semantic functions.

The role (dynamic semantic function) performed by the verb in a particular sentence in the immediately relevant context derives from the interplay of all the basic FSP factors. Apart from the semantic content of the verb (which seems to be primary), to a very large extent it depends on the contextual conditions as well as the linear modification of the sentence. In the context of the theory of FSP, the English verb either ascribes a quality to the subject, bridging its specification, or presents something new on the scene. As such, the verb (and its role in perspectivising the sentence either towards or away from the subject) definitely deserves a thorough treatment in terms of both dynamic and static semantics. 
Generally, English tends to operate in one of the dynamic semantic scales; however, some can be found in both, depending on their static semantic load, valency and complementation, and, above all their potential presentational capacity (cf. ADAM, 2011a, 2011b, 2011c). To illustrate, research has indicated that the more complex their valency (esp. on the right) is, the more probably these serve in the Quality Scale; analogously, the more is added semantically to the expression of existence, the more probably these serve in the Quality Scale. Compare the double usage of one verb in two different dynamic semantic scales:

A famine struck the country. (Context-independent subject; Presentation Scale)

(11) The clock struck five. (The subject is specified by the object; Quality Scale)

There have been identified basically two static semantic groups of verbs that may be seen clearly as those expressing the existence or appearance on the scene in an explicit way (ADAM, 2011a, 2011b). First, these are verbs of "going and coming" - e.g. come, arrive, enter, step in, fall, come down; second, these are verbs that convey the notion of appearance proper, such as appear, occur, be born, turn up. The Pr-verbs falling into the category of verbs of going and coming are, in their nature, dynamic and carry the meaning of certain motion. Fulfilling the Firbasian idea of existence on the scene, they mediate this existence from the dynamic point of view, placing emphasis on the motion process proper. Compare the following instances extracted from a research corpus ${ }^{3}$ :

(12) And a soon after that a very strange person stepped out from among the trees. (N13b)

(13) ... and from a hole in the roof smoke was going up. (N72a)

Such Pr-verbs denote a simple movement action performed by the phenomenon that is being presented on the scene of communication. The set of verbs as such is not extremely varied as to the meaning carried by the verbs; these verbs rather convey simple motion actions such as that of going, coming, following, or returning that actually lack any further specification of a more subtle meaning. The verbs of appearance proper, on the other hand, reflect exactly the definition of Firbasian appearance on the scene with explicitness. Such Pr-verbs are concerned more with the appearance per se rather than with the motion involved. It is possible to speak of appearance as a non-scalar, polar phenomenon; somebody or something appears on the scene without any prior presence, i.e. from zero to full existence. ... and horrible ideas came into his head. (N73b)

\footnotetext{
${ }^{3}$ The whole text under examination (C. S. Lewis' The Chronicles of Narnia: The Lion, the Witch and the Wardrobe, abbreviated and marked with $\mathrm{N}$ in the corpus) consists of ca 40,000 words and their FSP analyses. Within the corpus, there are 3,067 basic distributional fields, which are technically counted as finite clauses; non-finite clauses are regarded as separate communicative units within the basic distributional fields.
} 
(15) Instantly the same dwarf whom Edmund had seen with her before appeared. (N99c)

Interestingly, all different sorts of verbs capable of presenting a new phenomenon on the scene in an implicit way, such as await, buzz, wake (the silence), chirp, shine, were detected in the course of research (ADAM, 2011b). Seemingly, they come from different semantic groups of verbs and do not have much in common. The question may arise: what is the implicit semantic load that enables a verb to serve as Pr-verb in the Presentation Scale? What and where are the boundaries between the maximum degree of implicit expression of existence or appearance on the scene and a verbal content that allows only for a qualitative use of the verb in the Quality Scale?

The research shows that one of the most significant features of such Pr-verbs may be described as a certain degree of semantic affinity between the Pr-verb itself and the clause subject (ADAM, 2011c, cf. FIRBAS, 1992: 60). In other words, the action is so semantically inherent and subject-related that it is the subject that takes over the communicative prominence at the expense of power of the verbal content. The static semantics of the verb then - even if expressing a specific type of action - is reduced to that of presentation.

(16) A bee buzzed across their path. (N120e)

(17) At that moment a strange noise woke the silence. (N128) ... and gold flashed. (N179d)

Apart from the verbs denoting visual, acoustic and other sensory manifestation of an action (see ex. (16) - (18)), the Pr-verbs may be recruited from the semantic category of verbs denoting natural phenomena that are typically unaffected by people, such as weather - see (19a) and (20a). The presentational interpretation may be easily corroborated both by the placement of the nuclear stress on the rhematic subject in English and by the Czech corresponding equivalent translation of the clauses in which the rhematic subject - according to the principle of endfocus - invariably occupies the final position in the sentence - cf. (19b) and (20b):

(19a) Then a wind sprang up. (N92a).

(20a) And the moon came out. (N92c)

(19b) Pak se zvedl vitr.

[Then (refl.) sprang-up a-wind.]

(20b) A vyšel měsíc.

[And came-out the-moon.]

The action content of the verbal element is so natural and typical of the agent (cf. buzzing and the bee, or flashing and gold) that the full verb is employed from the point of view of dynamic semantics - to denote a form of existence or appearance on the scene. The verb that operates in semantic affinity with its subject semantically supports the character of the subject; in relation to this phenomenon, Firbas argues that via such semantic affinity "the verb prepares the way for the phenomenon to be presented" (FIRBAS, 1992: 61). 
In his summarising monograph, Firbas enumerates a number of Pr-verbs identified in his corpora (FIRBAS, 1992); here are some of these in alphabetical order: arrive, be in sight, become plain, come forward, come into view, come up, crop up, emerge, exist, evolve, develop, grow out of, happen, issue, recur, rise, spring up, show up, take place, etc. (for a full account of the Pr-verbs given by Firbas, see FIRBAS, 1992: 60-64). It can be readily claimed that all of these verbs are - in terms of their degree of expressing existence or appearance on the scene in an explicit or sufficiently implicit way - in full concordance with what the present analysis and current research suggest (see also DUŠKOVÁ, 2008). To name just a few Pr-verbs for the sake of illustration, here are those that were not detected by Firbas: be on the move, come out, come over, fall, happen, rush up, lie, sit, stand, stick, strike down, or sweep into sight and many others (for details see ADAM, 2011a, 2011b). The full range of Pr-verbs along with a more profound semantic analysis is a matter of future research in the field.

\section{Typology of Presentation sentences}

Based on the research that has been conducted in the past three years (ADAM, 2011a, 2011b), the following classification of Pr-sentences could be put forward as representative of the basic types of structures occurring in the various texts analyzed.

1. Existential construction

(21) There'll be hawks. (N9c)

2. Rhematic subject in preverbal position

(22) And now a very curious thing happened. (N70)

3. Subject-verb inversion

(23) And next to Aslan stood two leopards. (N125)

4. Locative thematic subject + rhematic object

(24) The banner bore a red rampant lion ... (N123d)

\subsection{Prosodic interpretation of Pr-sentences}

Some of the above listed types (particularly the first two) may come across as rather straightforward and easy to recognize, yet there could be instances that testify to the contrary. This is the point where intonation comes to play a part and - as has been mentioned earlier - helps to disambiguate the potentiality of meaning. Examples (25) and $(26)^{4}$ both offer two possibilities of prosodic interpretation (please note that for the sake of clarity the intonation centre bearer [the rheme] will be capitalized and preceded by a tonetic mark indicating the relevant nuclear tone):

\footnotetext{
${ }^{4}$ Examples (25) to (27) have been taken from a corpus of audio texts, created for the purpose of a comparative study of English intonation used by Czech speakers (HEADLANDOVÁ, 2010).
} 
(25a) The | DOCTOR is coming.

$\mathrm{Ph} \quad \mathrm{Pr}$

This way of reading presents an unmarked utterance, despite the non-final placement of intonation centre, which is often indicative of markedness. This is a special phenomenon, mentioned by various linguists, e.g. HALLIDAY distinguishes "certain high frequency collocations with reversed tonicity marking" (1967: 3839) while SCHMERLING comments on "news sentences", i.e. sentences introducing nothing but new information, which "receive accents on their arguments rather than their predicates" (as cited in GUSSENHOVEN, 1986: 88). However, should the same sentence be read with the intonation centre on the last lexical item (as would be expected especially by non-native speakers), the message conveyed would change, compare the following:

(25b) The doctor is $\backslash$ COMING. (not just going to phone, for example) $\mathrm{B}$ $\mathrm{Q}$

According to Halliday, this is then a "marked information point" (ibid.); in terms of FSP, the sentence is now oriented away from the subject and as such it becomes one of the Quality-Scale type.

Similarly, there are sentences described by CRUTTENDEN as "event / presentation sentences" (1986: 82-83), which in most cases display the following characteristics:

- they do not "observe" the general rule for the nucleus to fall on the last lexical item in a tone unit; the nucleus is carried by the subject,

- they are found especially in intransitive clause structures with inanimate nouns as subjects (HALLIDAY, 1967: 38-39),

- very generally, they refer to (dis)appearance or misfortune (CRUTTENDEN ibid.).

(26a) And the \ ROOF is leaking. [If ... ], the \CEILING will come down. $\mathrm{Ph} \quad \mathrm{Pr} \quad \mathrm{Ph} \quad \mathrm{Pr}$

This prosodic treatment would be felt as the "natural, appropriate" way of reading the utterance by most English native speakers, whereas speakers with a different linguistic background would have to be of a rather high level of proficiency in English to be able to produce it spontaneously. The most likely version of prosodic realization by many non-native speakers would shift the intonation centre to the finally-placed element, thus changing the perspective of the sentence, see example (26b).

(26b) And the roof is $\mathbf{L E A K I N G}$. (as opposed to having just a cracked tile) $\mathrm{B}$ $\mathrm{Q}$ [If ... ], the ceiling will come $\mathrm{DOWN}$. (it won't just peel off)

B

$\mathrm{Q}$ 
The above listed examples refer to sentences which perhaps do not come across as typical representatives of the Presentation Scale; they may seem "disguised" owing to the potentiality of meaning. Yet, there are numerous other cases where the sentences despite their obvious presentational character get misread / mispronounced and the meaning which they carry becomes distorted. Compare the following utterances:

(27a) (A: What are your plans for tomorrow?)

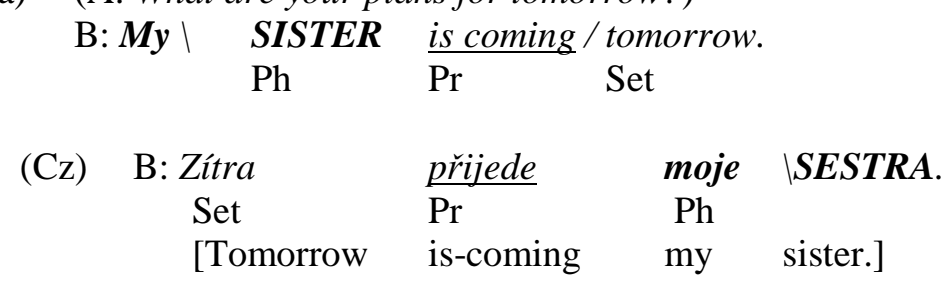

In both languages, utterance B maintains the same rheme - the intonation centre bearer - my sister / moje sestra, and equally, it displays a full implementation of the constituents of the Presentation Scale. It is only in Czech, however, that the linear arrangement coincides with the interpretative arrangement. In English, due to syntactic obligations, the Phenomenon comes first, therefore the intonation centre assigned to it has to be placed initially. This was the point where as many as $40 \%$ of the Czech speakers participating in the project on intonation (see HEADLANDOVÁ, 2010) faulted and shifted the intonation centre in most cases to the final lexical item. The exchange between speakers A and B then looked as follows:

(27b) (A: What are your plans for tomorrow?)

$\mathrm{B}$ : My sister is coming $\backslash$ TOMORROW.

B $\quad$ Q Sp

When read out loud, it is without a doubt a very conspicuous placement of the intonation centre, and within the immediately relevant context response B lacks coherence.

To sum up, the appropriate placement of the intonation centre is crucial if the prosodic factor is to participate efficiently in the interplay of the four factors determining the distribution of communicative dynamism in a sentence. On the contrary, an incorrect placement may affect the coherence of a particular utterance, as it can lead to confusion, thus generating the need for clarification, or possibly even result in complete misunderstanding on the part of the listener (HEADLANDOVÁ, 2010).

\section{Conclusions}

The present paper explores one of the crucial principles within information processing: there are two basic ways of how a sentence in the act of communication may be perspectived. Recent research into the area of the dynamic 
semantic scales has confirmed the applicability of the modification of the original framework of dynamic semantic scales developed by FIRBAS (1992) and supplemented by SVOBODA (1989). The modification consists in the recognition of the occurrence of a Specification within the Presentation Scale in semantically dense sentences (CHAMONIKOLASOVÁ, ADAM, 2005).

Research has clearly shown that the ratio between the incidence of sentences implementing the Presentation or the Quality Scale respectively may substantially differ in terms of various text types (see above all ADAM, 2010, 2011a, 2011b; HurtovÁ, 2010; ŘEZNíČKOVÁ, 2009; LingOVÁ, 2008). For example, religious written discourse generally displays higher percentage of Pr-Scale sentences, such as 9-12 percent in New Testament gospels and Pauline epistles. The incidence of Pr-sentences in fiction narrative usually ranks between 5-8 percent. Obviously, the incidence of Pr-sentences in the corpus under investigation is due to stylistic qualities relatively high, especially in comparison with an extremely low occurrence of Pr-Scale sentences in the Internet chat or e-mail communication. The general variability in terms of incidence of Pr-sentences in different genres is also illustrated by the table below:

Table 1: Incidence of Pr-sentences across genres

\begin{tabular}{|l|c|l|}
\hline \multicolumn{1}{|c|}{ (Sub-)genre } & Incidence in \% & \multicolumn{1}{c|}{ Reference Sources } \\
\hline Internet chat & $1-2$ & ADAM, 2011c \\
\hline E-mails & $2-3$ & HURTOVÁ, 2010 \\
\hline biblical poetic text & $3-6$ & ADAM, 2009 \\
\hline fiction narrative & $5-8$ & $\begin{array}{l}\text { ADAM, 2009, 2011a, 2011b; } \\
\text { HURTOVÁ, 2010; } \\
\text { ŘEZNÍČKOVÁ, 2009 }\end{array}$ \\
\hline biblical narrative & $9-12$ & ADAM, 2011c \\
\hline technical text & $>30$ & $\begin{array}{l}\text { LINGOVÁ, 2008, } \\
\text { REZNÍČKOVÁ, 2009 }\end{array}$ \\
\hline
\end{tabular}

The present paper also strove to demonstrate the significance of the English transitional verb in the framework of the dynamic semantic scales; the verb definitely proves to be one of the decisive operators in the syntactic semantic perspective of the sentence that is capable of tipping the scales in favour of Quality or Presentation. Apart from the three basic FSP factors, the semantic affinity between the verb and the subject was found to represent a vital moment in perspectivising the sentence towards the presentational interpretation.

The analysis evidently speaks in favour of a fruitful interface of both the dynamic semantics (FSP) and static semantics towards language material. Not only is such an approach a helpful tool for a more in-depth FSP analysis, but it also appears to make the FSP interpretation more precise. Regarding the future research, a larger corpus of Presentation sentences and their analysis should definitely be made, along with a more detailed analysis of the syntactic semantic features of Pr-verbs (especially syntactic characteristics such as verb valency, complementation or transitivity). In addition, a functional comparison of various genres and registers in terms of Pr-Scale sentences should identify further 
significant differences as all these issues generally represent promising steps in FSP research into the phenomenon of the dynamic semantic scales.

\section{REFERENCES}

ADAM Martin (2003), Religious Text: the Thematic and the Rhematic Layers within a Distributional Macrofield, Brno, Masaryk University.

ADAM Martin (2009), Functional Microfield Perspective: A Religious Discourse Analysis Based on FSP, Brno, Masaryk University.

ADAM Martin (2011a), "A bee buzzed across their path". Semantic Affinity as a Formative Force in Presentation Scale Sentences, Ostrava Journal of English Philology 3/1, Ostrava, Ostravská univerzita, p. 19-32.

ADAM Martin (2011b), On Some Specific FSP Features of Presentation Scale Sentences in the Gospel of Luke, New Chapters in Functional Syntax, Ostrava, University of Ostrava, p. 9-17.

ADAM Martin (2011c), Towards a Syntactic-Semantic Typology of Presentation Scale Sentences in Fiction Narratives, Brno Studies in English 37/1, p. 5-19.

AMMANN Othmar (1911), Die Stellungstypen des lateinischen attributiven Adjectivums und ihre Bedeutung für die Psychologie der Wortstellung auf Grund von Ciceros Briefen an Atticus untersucht, Idg. Forschungen 29, p. 122.

BRASSAI Sámuel (1860), A magyar mondat I. [The Hungarian sentence], A Nyelvés Széptudományi Osztály Közlönye, Pest, Emich, p. 279-399.

Chamonikolasová Jana (2005), Dynamic semantic scales in the theory of functional sentence Perspective, Aleg(r)ace pro Evu. Papers in Honour of Eva Hajičová, Praha, FF UK, p. 61-67.

Chamonikolasová Jana, Adam Martin (2005), The Presentation Scale in the Theory of Functional Sentence Perspective, Patterns (A Festschrift for Libuše Dušková), Praha, FF UK, p. 59-69.

CRUTTENDEN Alan (1986), Intonation, Cambridge, Cambridge University Press.

DUŠKOVÁ Libuše (1998), Syntactic forms of the presentation and their differentiation, Linguistica Pragensia 8 (1), p. 36-43.

DUŠKOVÁ Libuše (2008), Vztahy mezi sémantikou a aktuálním členěním z pohledu anglistických členů Pražského lingvistického kroužku, Slovo a slovesnost 69 (1-2), p. 67-77.

FIRBAS Jan (1979), A functional view of 'ordo naturalis'. Brno Studies in English, 13, Brno, p. 29-59.

FIRBAS Jan (1992), Functional Sentence Perspective in Written and Spoken Communication, Cambridge, Cambridge University Press.

FIRBAS Jan (1995), On the thematic and the rhematic layers of a text, Anglicana Turkuensia 14, p. 59-72. Cambridge, Cambridge University Press.

Gussenhoven Carlos (1986), The Intonation of 'George and Mildred': PostNuclear Generalisations, Intonation in Discourse, Beckenham, Croom Helm Ltd., p. 77-124.

HALLIDAY Michael Alexander Kirkwood (1967), Intonation and Grammar in British English, The Hague, Mouton. 
HeAdlandová KALISCHOVÁ Irena (2010), Intonation in Discourse: English intonation as (mis)used by Czech speakers, Brno, Masaryk University.

HuRTOVÁ Zuzana (2010), Analyzing e-mails from the viewpoint of FSP, Ostrava Journal of English Philology, 2/2, p. 21-30.

KIEFER Ferenc (2005), On the information structure of the Hungarian sentence, Hungarian Studies 19/2, Budapest, Adadémiai Kiadó, p. 255-265.

LEWIS Clive Staples (1950), The Chronicles of Narnia. The Lion, the Witch and the Wardrobe, London, Harper Collins.

LingOVÁ Lenka (2008), Some Aspects of the Dynamic - Semantic Tracks within the Theory of FSP, Brno, Masaryk University.

LEŠKA Oldřich (2002), Anton Marty's Philosophy of Language, Prague Linguistic Circle Papers 4/2002, Amsterdam, John Benjamins Publishing Co. , p. 83-99.

MATHESIUS Vilém (1975), A functional analysis of present day English on a general linguistic basis, The Hague, Mouton.

ŘEZNÍČKOVÁ Ivana (2009), Thoughts on the semantic relationship between direct speech and reporting clause with regards to FSP, Ostrava Journal of English Philology 1/2, 67-77.

SCHMERLING S. F. (1976), Aspects of English sentence stress, Austin, University of Texas Press.

SGAll Petr, HAJIČová Eva, BurÁŇOvÁ Eva (1980), Aktuální členění věty $v$ češtině [Functional sentence perspective in Czech], Praha, Československá akademie věd.

SvoBodA Aleš (1989), Kapitoly z funkční syntaxe [Chapters from functional syntax], Praha, SPN.

SvoBodA, Aleš (2005), Firbasian semantic scales and comparative studies. In: Čermák, J. et al. (eds.), Patterns (A Festschrift for Libuše Dušková). Praha, Charles University, p. 217-229.

WEIL Henri (1844), De l'ordre des mots dans les langues anciennes comparées aux langues modernes, Amsterdam, John Benjamins. 


\title{
Résumé en français
}

\section{La notion d'échelles sémantiques dynamiques dans la théorie de la perspective fonctionnelle de la phrase}

\author{
Martin ADAM \\ Irena HEADLANDOVÁ KALISCHOVÁ \\ Université Masaryk, Brno
}

La théorie de la perspective fonctionnelle de la phrase (PFP) et ses méthodes de recherche sont considérées comme un des instruments importants des recherches portant sur la manière de traiter les informations. Englobant les approches du point de vue des formalistes et des fonctionnalistes, cette théorie s'appuie dans une large mesure sur les acquis présentés par les linguistes de l'École de Prague, notamment par Vilém Mathesius. V. Mathesius a décrit le fait que chaque énoncé contient un thème et un rhème en tant qu'un des universaux linguistiques et a posé ainsi les bases d'une théorie appelée plus tard PFP. Dans le cadre de cette théorie, chaque phrase est une réalisation d'une des soi-disant échelles sémantiques dynamiques (Firbas, 1992), qui représentent le degré de la dynamique communicationnelle et fonctionnent sans tenir compte de l'ordre des mots. M. Firbas distingue en principe deux types des échelles en question: une échelle présentative où est réalisée une présentation sur la scène d'un sujet contextuellement non intégré, et une échelle qualificative où une qualité est attribuée au sujet.

La présente étude a pour but de présenter la notion des échelles sémantiques dynamiques du point de vue diachronique et dans ce but elle utilise une comparaison d'ouvrages importants de différents auteurs tchèques depuis Mathesius, en poursuivant avec Firbas et Svoboda, jusqu'à Chamonikolasová et Adam. Outre les représentants cités de l'École de Prague et de l'École de Brno, on mentionne encore d'autres linguistes qui, bien que moins connus, furent de véritables pionniers du champ des théories des structures informationnelles, cf. Henri Weil, Sámuel Brassai, Georg von der Gabelentz, Hermann Paul et Anton Marty.

Nous tâchons aussi de faire ressortir le rôle important du verbe anglais dans la fonction de transit dans le cadre des échelles sémantiques dynamiques, car c'est justement le verbe qui appartient parmi les facteurs de la perspective syntacticosémantique de la phrase ayant la capacité de décider si l'aiguille de la balance imaginaire penchera du côté présentatif ou du côté qualificatif de l'échelle. Les résultats des analyses faites jusqu'ici montrent de façon convaincante que l'on peut mettre à profit une réunion de la sémantique dynamique (PFP) et de la sémantique statique. Grâce à cette réunion, il devient possible de faire les analyses plus profondes du matériel linguistique et de préciser en même temps la méthode même de la PFP. Quant aux recherches futures, un but clair s'impose : créer un corpus plus grand de phrases «présentatives » et faire leur analyse ensemble avec une analyse plus détaillée des propriétés syntactico-sémantiques des verbes apparaissant dans les échelles présentatives. 